\title{
KONSEP DERAJAT MANUSIA MENURUT ALQURAN DALAM MENANGGAPI PENDERITAAN
}

\author{
Siti Shafa Marwah ${ }^{1}$, Endis Firdaus ${ }^{2}$, Wawan Hermawan ${ }^{3}$ \\ ${ }^{1}$ Universitas Pendidikan Indonesia, Email: shafa.siti@student.upi.edu \\ ${ }^{2}$ Universitas Pendidikan Indonesia, Email: endisf@upi.edu \\ ${ }^{3}$ Universitas Pendidikan Indonesia, Email: wawan.h1960@upi.edu
}

\begin{abstract}
ABSTRAK
Manusia memiliki cara yang berbeda dalam menanggapi permasalahan hidup, cuplikan penderitaan yang dirasakan oleh manusia dalam kehidupan sehari-hari, seperti korban dari tindak kejahatan, diuji dengan sakit keras, himpitan ekonomi, dan sebagainya. Tidak jarang sebagian orang melakukan kesalahan, karena belum berdamai dengan perasaan menderita, ini wajar dirasakan oleh kita karena tidak paham mengenai tujuan apa yang sebenarnya ada dibalik penderitaan yang dirasakan. Kajian ini terinspirasi dari orang-orang yang berhasil melalui masa pederitaannya, dan mau berbagi atas kisahnya di media massa. Maka peneliti ingin mencari makna khusus mengenai penderitaan dan kaitannya atas tingat derajat manusia, dengan sudut pandang Alquran, agar setiap pembaca memahami penderitaan dalam perspektif yang menurtnya baru. Metode dalam kajian ini menggunakan pendekatan Tafsir Tematik dan dibantu metode Quran Digital, dengan menelusuri kata kunci yang berkaitan dengan kajian ini, beserta devariatnya. Hasil menunjukkan bahwa, baik dulu maupun sekarang, dibutuhkan kemauan dan ilmu dalam mengelola emosi saat merasakan penderitaan, tinggi derajatnya seseorang tidak sebatas dia cukup beriman saja, tetapi diperlukan amal yang lebih besar, serta dibarengi kerelaan saat dihadapkan pada situasi sulit yang membuatnya menderita. Bahkan derajat seseorang bisa saja menurun, saat ia tidak bersabar menjalani penderitaan, namun saat ia sadar atas kesalahannya tersebut, Allah masih terus memberikan kesempatan bagi manusia yang mau terus belajar. Kajian ini memiliki implikasi, mampu membangun persepsi baru seseorang, dalam memaknai permasalahan di sekitar ruang lingkup kehidupannya.
\end{abstract}

Kata Kunci: Masalah Hidup; Penderitaan; Derajat Manusia; Kemuliaan; Quran Digital.

\begin{abstract}
Humans have different ways of dealing with life's conflicts, capturing the challenges felt by humans in everyday life, as well as victims of crime, remembering hard, economic crush, and so on. It is not uncommon for people to make mistakes, because they have not yet reconciled with the feelings they have experienced, this is accepted by us because they do not understand the true purpose behind the consideration received. This study was inspired by people who made it through the suffering, and were willing to share their stories in the mass media. Therefore, the researchers want to find a specific meaning about the discussion and discussion of human degrees, with the viewpoint of the Koran, so that each reader can understand the perspective that is new. The method in this study uses Thematic Interpretation and accepts the Digital Quran method, by sharing keywords related to this study, along with the devariate. The results show, both past and present, it requires the will and knowledge needed when needed, the high degree of a person is not limited to just believing, need greater charity, and is willing to be willing when confronted when difficult times are needed. While a person's degree may decline, when he is not patient in overcoming difficulties, but when he is aware of these mistakes, God continues to provide opportunities for people who want to continue learning. This study has implications, able to build one's perception, in interpreting the debate around the discussion space of his life.
\end{abstract}

Keywords: Problems of Life; Victory; Humanity; Glory; Digital Quran 


\section{PENDAHULUAN}

Manusia ada di dunia dengan berbagai macam rupa, bentuk, dan rezeki yang sudah lebih dulu ditentukan oleh Tuhan. Penentuan hal-hal tersebut diberi berdasarkan kesanggupan penerimanya, tetapi pada kenyataannya yang terjadi hari ini, sebagian manusia masih mudah merasa kecewa, sehingga mereka menyalahkan Tuhan atas apa yang mereka alami (Wiryoutomo, 2009: 4). Dalam penelitian Daradjat ditemukan bahwa, hal tersebut sangat berkaitan dengan peranan emosi yang dimiliki manusia (Daradjat, 2010: 189). Manusia yang lebih banyak dikuasai oleh emosinya, mudah terkena sugesti saat dirinya berada dalam perasaan gelisah maupun kecewa. Dia akan berusaha mencari tempat baru, untuk melepaskan tekanan perasaan penderitaan yang dirasakan dan mendapatkan sesuatu yang menurutnya bisa mendamaikan hatinya (Daradjat, 2010: 188).

Mengenai penderitaan manusia, terdapat pula hasil penelitian Shihab yang menyatakan, bahwa itu terjadi karena nalar manusia terbatas, kita tidak bisa memasuki semua dimensi (Shihab, 2000: 121). Manusia perlu memandang kejadian alam dengan pandangan yang menyeluruh, supaya mendapatkan unsur kebaikan dan keindahan dalam menanggapinya. Saat manusia memandang secara mikro atas suatu kejadian, maka seperti emosi yang sebelumnya dilaporkan oleh Daradjat bisa muncul dan mengganggu pemikiran kita yang positif mengenai Tuhan. Bahkan Shihab memberikan solusi, ketika tidak bisa memahami sesuatu dengan sudut pandang yang makro, maka orang tersebut harus meyakini bahwa setiap kejadian, memiliki hikmah yang indah bagi penerima maupun bagi manusia yang mempelajarinya (Shihab, 2000).

Kajian yang dilakukan oleh Darmawanti ikut memperkaya penjelasan mengenai pengaruh rasa penderitaan dalam artikel ini. Berdasaran laporannya, terdapat istilah dalam ilmu psikologi, yakni coping stress (Darmawanti, 2012). Ini meupakan reaksi seseorang dalam memanajemen keadaan dirinya yang sedang mengalami stres. Keadaan jiwa manusia yang berbeda-beda, membuat setiap individu harus terus menemukan caranya sendiri, untuk bisa sampai pada tahap meredakan bahkan menghilangkan stresnya. Tentu dengan melihat teori psikologi tersebut, timbul pemahaman bahwa seorang individu harus menemukan cara yang positif, karena cara yang positif cenderung efektif kedepannya. Ini selaras dengan hasil penelitiannya yang menemukan kesimpulan berupa, semakin tinggi tingkat religiusitas seseorang, semakin tinggi pula coping stressnya (Darmawanti, 2012).

Rasulullah saw. sebagai panutan utama umat Muslim, sudah memberikan banyak contoh yang serupa dengan coping stress. Ini sejalan dengan kajian yang dilakukan Wage melalui analisisnya terhadap QS. Al-Anbiya:107, misi utama Islam sendiri adalah sebagai pembawa rahmat, yang didalamnya memuat kasih sayang dan kebaikan, sehingga mustahil Rasulullah membawa solusi yang memberatkan dan merugikan manusia (Wage, 2015). Beberapa solusi ditawarkan oleh Rasulullah 
SAW, seperti yang dilaporkan dalam kajian (Kumala, Kusprayogi, \& Nashori, 2017) dan (Hasan, 2017) zikir merupakan salah satu cara yang baik untuk mengelola emosi manusia. Dengan melakukan kegiatan zikir secara rutin, bisa membuat individu fokus terhadap ketegangan emosi yang dirasakan, sekaligus melatihnya menjadi rileks.

Cara lainnya yang bisa digunakan untuk pengendalian emosi adalah dengan bersikap husnuzan (berprasangka baik), empati terhadap keadaan orang lain, altruisme, bersyukur, bersabar, dan ikhlas memaafkan. Ini adalah strategi yang biasa dilakukan oleh Rasulullah saw., karena hebatnya dampak yang diberikan, hal ini bahkan diterapkan oleh ilmu psikologi dalam menangani kliennya (Nadhiroh, 2015). Tenyata berdasarkan kajian yang dilaporkan oleh Istiningtyas, terdapat satu cara lain juga yang biasa dilakukan oleh Rasulullah saw,. yakni dengan bercanda secara positif, mengajak orang lain untuk tertawa. Manfaat bercanda dan tertawa cukup besar pengaruhnya bagi fisik maupun psikologis, yang secara khusus bisa menjadi ketenangan bagi yang sudah mengalami usaha keras ntuk mencapai sesuatu, dan memunculkan kebahagiaan setelah merasakan emosi yang negatif (Istiningtyas, 2014).

Berdasarkan kajian di atas, ternyata emosi manusia mudah sekali berubah tergantung keadaan yang mengitarinya. Pada zaman ini pun, manusia cenderung memiliki rutinitas yang hampir sama setiap tahunnya, sehingga secara tidak sadar mempengaruhi kepribadian orang tersebut. Kita pun menyadari bahwa perawatan atas diri kita, tidak hanya sebatas pada fisiknya saja, namun kesehatan psikologis juga perlu mendapatkan hal yang sama. Saat manusia bisa mengolah emosinya dengan baik, apakah memiliki keterhubungan dengan tingkat kedudukannya di mata Allah dalam Alquran?, bagaimana jika seseorang yang sedang tidak bisa mengelola emosinya dan melakukan hal negatif, apa berpengaruh juga atas derajatnya?, lalu bagaimana jika orang tersebut bertaubat, apakah ia mendapatkan kembali derajat yang mulia?. Oleh karena itu, artikel ini bermaksud untuk menjawab pertanyaan-pertanyaan tersebut, berdasarkan penjelasan Alquran selaku acuan bagi umat Islam. Untuk memudahkan pemahaman atas tema ini, maka diperlukan metode Digital Quran dalam menemukan ayat-ayat yang berkaitan secara komprehensif, serta mengkajinya dari sudut tafsir Alquran untuk menggali makna yang terkandung oleh setiap ayat serta meminimalisir kesalahan dalam memahami makna ayat Alquran yang berkaitan dengan tema.

\section{METODE}

Metode yang digunakan dalam artikel ini, menggunakan pendekatan Tafsir Tematik dan dibantu metode Quran Digital. Hal ini dilakukan karena metode tafsir tematik yang dinamis, sehingga tidak kaku dalam membahas ayat demi ayat, tetapi mampu memberikan pemahaman yang cukup luas, dalam menjawab tema yang diajukan (Supiana, 2017: 160). Untuk memilih pendekatan ini, penulis melihat 
terlebih dahulu permasalahan yang cenderung terjadi di masyarakat. Fenomena yang terlihat penulis saat ini, adalah tingkat ketahanan masyarakat modern dalam menerima salah satu emosi atau perasaan, yang menurut mereka sebuah penderitaan bagi diri mereka. Permasalahan dan kejahatan sangat eksis sejak dulu, tetapi ketahanan masyakat dalam menanggapinya berbeda pada setiap masa. Sehingga muncul kemauan untuk menelaah tentang perasaan menderita dalam Alquran, dan bagaimana pengaruhnya terhadap derajat kemanusiaannya di mata Tuhan.

Penulis menggunakan metode tambahan disamping menggunakan metode tafsir tematik, yakni metode Quran Digital, untuk mengefektifkan waktu penelitian. Tahapan metode Quran Digital mirip dengan Tafsir Tematik, hanya saja metode Quran Digital berbasis aplikasi. Hal pertama yang dilakukan adalah kita perlu menuliskan tema yang akan dibahas pada kolom yang sudah disediakan, maka akan tertulis jumlah ayat-ayat mana saja yang membahas tema yang diusung (Rahmat, 2017), dan tema yang kita bahas adalah Penderitaan dan Derajat.

Tahapan selanjutnya, setelah ayat-ayat tentang Penderitaan dan Derajat sudah didapat, maka selanjutnya dituliskan dalam bentuk tabel, dan di setiap tabel dimasukan 10 ayat saja, jika masih ada ayat lainnya yang belum ditabelkan, maka buat tabel kedua (tabel yang baru) dan seterusnya, ini bertujuan untuk memudahkan peneliti dalam menganalisis, dan mencari korelasi antara satu ayat dengan ayat yang lainnya. Peneliti berusaha untuk mencari pesan ayat yang berhubungan dengan tema Penderitan dan Derajat. Setiap ayat akan ditemukan pesan yang berisi penjelasan tentang Penderitaan dan Derajat, maka peneliti bisa menuliskan kesimpulan sementara di setiap ujung penjelasan ayat-ayat tersebut.

Setelah semua ayat tentang Penderitaan dan Derajat yang ditemukan melalui proses diatas, maka peneliti bisa menganalisis kembali melalui kesimpulan-kesimpulan sementara, lalu dibuat menjadi kesimpulan akhir, yang bisa mencakup semua pesan, dari ayat yang sama-sama membahas Pendertitaan dan Derajat, dengan begitu peneliti mampu secara jelas menjawab rumusan masalah (Rahmat, 2017).

Kegiatan analisis terhadap Konsep Derajat Manusia menurut Alquran dalam Menanggapi Penderitaan, menggunakan metode Pembelajaran Digital Quran secara Tematik ini, setelah ditelusuri dengan kata kunci "Derajat", ditemukan sebanyak 18 ayat yang membicarakan konsep derajat dalam Al-Quran. Sebenarnya, sudah dijelaskan juga sebelumnya, ada beberapa devariat kata yang terkait dengan kata kunci "Derajat", seperti "Kedudukan", "Tingkatan", dan "Martabat". Namun, karena peneliti ingin benar-benar fokus menggunakan kepenulisan metode Digital Quran Tematik dalam pencarian kata Derajat, maka peneliti menggunakan kata kunci "Derajat" saja. Penelusuran yang menemukan adanya 18 ayat ini pada akhirnya peneliti ringkas menjadi 15 item, karena terdapat beberapa ayat yang memiliki keterhubungan antara satu dengan yang lainnya. Penelusuran dilanjutkan 
dengan menggunakan kata kunci "Penderitaan", ditemukan 4 ayat yang memiliki pembahasan kata tersebut secara bahasa.

Sudah disebutkan diawal bahwa artikel ini menggunakan dua metode yang saling melengkapi, pada saat ditemukan sejumlah ayat yang cocok dengan pembahasan dengan metode Quran Digital, ayat-ayat tersebut diambil pesannya dengan cara melibatkan kitab tafsir untuk menafsirkan setiap kalimatnya. Kitab tafsir yang digunakan saat tahap analisis ayat di penelitian ini adalah kitab Tafsir al-Mishbah, karena mufasirnya sering melakukan kajian tafsir tematik, dan sudah dibuat dalam beberapa buku. Sehingga kedua metode ini, bisa digunakan secara baik, selama proses pengerjaan penelitian ini.

\section{HASIL DAN PEMBAHASAN}

\section{Penderitaan}

Pembahasan akan dimulai dengan hasil penelusuran dengan kata kunci "Penderitaan" terlebih dahulu melalui aplikasi Quran Digital, lalu pengambilan pesan ayat dengan mengkaji Tafsir Al-Mishbah. Ditemukan ada 4 ayat yang menyebutkan kata penderitaan, diantaranya adalah QS. Al-Baqarah: 177, QS. Al-A'raf: 94, QS. Al-A'raf: 95, dan QS. At-Taubah: 128.

Tabel 1. Memaknai Penderitaan

\begin{tabular}{|c|c|c|c|c|}
\hline No & $\begin{array}{l}\text { QS.: } \\
\text { Ayat }\end{array}$ & Terjemah Alquran & Pesan Ayat & $\begin{array}{c}\text { Kesimpulan } \\
\text { Sementara }\end{array}$ \\
\hline 1 & 2: 177 & $\begin{array}{l}\text { Bukanlah menghadapkan } \\
\text { wajahmu ke arah timur dan } \\
\text { barat itu suatu kebajikan, } \\
\text { akan tetapi sesungguhnya } \\
\text { kebajikan itu ialah beriman } \\
\text { kepada Allah, hari kemudian, } \\
\text { malaikat-malaikat, } \\
\text { kitab-kitab, nabi-nabi dan } \\
\text { memberikan harta yang } \\
\text { dicintainya kepada } \\
\text { kerabatnya, anak-anak yatim, } \\
\text { orang-orang miskin, musafir } \\
\text { (yang memerlukan } \\
\text { pertolongan) dan orang-orang } \\
\text { yang meminta-minta; dan } \\
\text { (memerdekakan) hamba } \\
\text { sahaya, mendirikan shalat, } \\
\text { dan menunaikan zakat; dan } \\
\text { orang-orang yang menepati } \\
\text { janjinya apabila ia berjanji, } \\
\text { dan orang-orang yang sabar } \\
\text { dalam kesempitan, } \\
\text { penderitaan dan dalam }\end{array}$ & $\begin{array}{l}\text { Diantaranya orang } \\
\text { yang sabar dalam } \\
\text { menjalani } \\
\text { kesempitan, } \\
\text { penderitaan, dan } \\
\text { dalam peperangan } \\
\text { sudah melakukan } \\
\text { kebajikan. } \\
\text { Orang-orang } \\
\text { tersebut termasuk } \\
\text { individu yang } \\
\text { benar-benar } \\
\text { beriman dan } \\
\text { bertakwa. }\end{array}$ & $\begin{array}{lr}\text { Orang yang sabar } \\
\text { ketika menderita } \\
\text { berarti } \\
\text { melakukan } \\
\text { kebajikan, dan } \\
\text { termasuk } & \text { orang } \\
\text { yang } & \text { benar } \\
\text { beriman } & \text { dan } \\
\text { bertakwa. } & \end{array}$ \\
\hline
\end{tabular}




\begin{tabular}{|c|c|c|c|c|}
\hline & & $\begin{array}{l}\text { peperangan. Mereka itulah } \\
\text { orang-orang yang benar } \\
\text { (imannya); dan mereka itulah } \\
\text { orang-orang yang bertakwa. }\end{array}$ & & \\
\hline 2 & 7: 94 & $\begin{array}{l}\text { Kami tidaklah mengutus } \\
\text { seseorang nabi pun kepada } \\
\text { sesuatu negeri, (lalu } \\
\text { penduduknya mendustakan } \\
\text { nabi itu), melainkan Kami } \\
\text { timpakan kepada } \\
\text { penduduknya kesempitan dan } \\
\text { penderitaan supaya mereka } \\
\text { tunduk dengan merendahkan } \\
\text { diri. }\end{array}$ & $\begin{array}{l}\text { Manusia diberi } \\
\text { penderitaan karena } \\
\text { suatu sebab, dengan } \\
\text { tujuan agar tunduk } \\
\text { dan merendahkan } \\
\text { diri. }\end{array}$ & $\begin{array}{l}\text { Penderitaan } \\
\text { datang karena } \\
\text { kesalahan yang } \\
\text { diperbuat } \\
\text { sebelumnya. }\end{array}$ \\
\hline 3 & 7: 95 & $\begin{array}{l}\text { Kemudian Kami ganti } \\
\text { kesusahan itu dengan } \\
\text { kesenangan hingga keturunan } \\
\text { dan harta mereka bertambah } \\
\text { banyak, dan mereka berkata: } \\
\text { "Sesungguhnya nenek } \\
\text { moyang kami pun telah } \\
\text { merasai penderitaan dan } \\
\text { kesenangan", maka Kami } \\
\text { timpakan siksaan atas mereka } \\
\text { dengan sekonyong-konyong } \\
\text { sedang mereka tidak } \\
\text { menyadarinya. }\end{array}$ & $\begin{array}{l}\text { Manusia merasa } \\
\text { adanya penderitaan } \\
\text { adalah hal yang } \\
\text { wajar terjadi, } \\
\text { karena nanti akan } \\
\text { diganti dengan } \\
\text { kesenangan }\end{array}$ & $\begin{array}{l}\text { Sebagian manusia } \\
\text { tidak } \\
\text { ber-muhasabah } \\
\text { atas tejadinya } \\
\text { penderitaan. }\end{array}$ \\
\hline 4 & 9: 128 & $\begin{array}{l}\text { Sesungguhnya telah datang } \\
\text { kepadamu seorang rasul dari } \\
\text { kaummu sendiri, berat terasa } \\
\text { olehnya penderitaanmu, } \\
\text { sangat menginginkan } \\
\text { (keimanan dan keselamatan) } \\
\text { bagimu, amat belas kasihan } \\
\text { lagi penyayang terhadap } \\
\text { orang-orang mukmin. }\end{array}$ & $\begin{array}{l}\text { Rasul selalu } \\
\text { memikirkan } \\
\text { kebaikan umatnya, } \\
\text { tidak ingin umatnya } \\
\text { menderita. }\end{array}$ & $\begin{array}{lr}\text { Seorang rasul } \\
\text { selalu mendoakan } \\
\text { untuk } \\
\text { keselamatan } \\
\text { umatnya, dari } \\
\text { penderitaan yang } \\
\text { dirasakan. }\end{array}$ \\
\hline
\end{tabular}

Melalui 4 ayat di atas, diketahui bahwa penderitaan datang bukan karena tiba-tiba tanpa alasan, tetapi ada penyebab yang membuatnya datang dalam kehidupan kita. Penderitaan datang, tergantung dengan pilihan tindakan apa yang kita ambil dalam menanggapi setiap kejadian. Contohnya, ketika diberikan kemudahan dalam mendapatkan keuntungan penjualan, tentu selanjutnya kita akan dihadapkan pada sebuah pilihan, "keuntungan yang didapat akan digunakan untuk apa?", saat memutuskan untuk menggunakannya dalam kegiatan yang mencelakakan orang lain, penderitaan melalui hasil proses hukum yang justru kita terima.

Jika menggunakan pendekatan penafsiran didapatkan bahwa dalam QS. Al-Baqarah: 177, memiliki penjelasan bahwa berhasil melalui penderitaan, 
merupakan salah satu contoh kebajikan sempurna dari sisi yang lahir ke permukaan, tidak sebatas ritualitas saja (Shihab, 2002: 468). Saat setiap individu bersabar menderita, maka dia dianggap benar beriman yang memiliki maksud antara sikap, ucapan, dan perbuatannya benar sekaligus sesuai (Shihab, 2002: 469).

Selanjutnya dalam QS. Al-A'raf: 94-95, ditemukan penjelasan bahwa penderitaan bisa bermakna kemiskinan, penyakit, krisis yang beragam, kesusahan yang berkaitan dengan jiwa seperti kebodohan, kegelisahan, kemudian bisa juga cacat fisik, kehilangan kedudukan, atau harta benda. Pada ayat 94 dan 95 terdapat keterhubungan pembahasan, dalam ayat 94 Allah masih memberikan kesempatan kepada manusia yang membangkang dengan cara penyadaran melalui rasa sakit dan penderitaan (Shihab, 2002: 213). Kemudian di ayat 95 Allah kembali memberikan perhatian-Nya dengan cara memberikan nikmat setelah kesedihan, namun yang terjadi manusia hanya menganggap kejadian tesebut sebatas siklus alam, setelah kesedihan maka akan muncul kesenangan. Mereka tidak berpikir bahwa kesenangan tersebut adalah salah satu ujian dari Allah (Shihab, 2002: 215).

Terakhir merupakan QS.At-Taubah: 128, didalamnya menjelaskan mengenai penderitaan umat Muslim, Rasulullah sangat mengerti bahwa keadaan masa itu sangat membuat mereka menderita, namun menjalani tugas sembari merasakan kesulitan tersebut pada dasarnya untuk kemaslahatan mereka, jadi penderitaan disini bukan terjadi karena sebuah kesalahan tetapi memang ujian yang datangnya secara berturut (Shihab, 2002: 302). Menurut asbabunnuzul QS. At-Taubah melalui ayat 81 yang berhubungan dengan hal ini, ditemukan penderitaan yang dimaksud adalah umat Muslim harus tetap berangkat perang meski sedang mengalami kesusahan ekonomi dan teriknya cuaca saat itu (Chirzin, 2012: 368), Rasulullah tentu tidak tega melihatnya, namun Perang Tabuk sendiri bertujuan untk mendapatkan kedamaian dengan menghadapi pasukan Romawi (Fakhyadi, 2017).

Dengan kesimpulan secara keseluruhan, penderitaan memang akan selalu ada, meskipun umat Islam terdahulu bersama Rasulullah, melihat contoh pribadi Rasulullah secara langsung, mereka tetap kewalahan dalam mengelola emosi dan menjaga keimanan mereka saat dihadapkan penderitaan. Penderitaan ada karena kesalahan manusia dalam memilih tindakan yang salah, dan bisa juga ada karena merupakan salah satu bagian dari ujian Allah swt untuk meningkatkan derajat manusia sekaligus ketahanan iman mereka.

\section{Derajat}

Hasil penelusuran kata kunci derajat pun memiliki cukup banyak pembahasan didalamnya, dengan kategori rumusan pembahasannya adalah: (1) Cukup beriman saja, mendapatkan derajat yang mulia; (2) Perilaku secara spesifik yang bisa meningkatkan derajat manusia; (3) Manfaat yang dirasakan, dengan ditingkatkan derajatnya. 
Tabel 2.a. Memaknai Kata Derajat

\begin{tabular}{|c|c|c|c|c|}
\hline No & $\begin{array}{l}\text { QS.: } \\
\text { Ayat }\end{array}$ & Terjemah Al-Quran & Pesan Ayat & $\begin{array}{c}\text { Kesimpulan } \\
\text { Sementara }\end{array}$ \\
\hline 1 & $2: 253$ & $\begin{array}{l}\text { Rasul-rasul itu Kami lebihkan } \\
\text { sebagian mereka atas sebagian } \\
\text { yang lain. Di antara mereka ada } \\
\text { yang Allah berkata-kata } \\
\text { (langsung dengan dia) dan } \\
\text { sebagiannya } \\
\text { meninggikannya } \\
\text { derajat. Dan Kami beberapa } \\
\text { kepada Isa putera Maryam } \\
\text { beberapa mukjizat serta Kami } \\
\text { perkuat dia dengan Ruhul } \\
\text { Qudus. Dan kalau Allah } \\
\text { menghendaki, niscaya tidaklah } \\
\text { berbunuh-bunuhan orang-orang } \\
\text { (yang datang) sesudah } \\
\text { rasul-rasul itu, sesudah datang } \\
\text { kepada mereka beberapa macam } \\
\text { keterangan, akan tetapi mereka } \\
\text { berselisih, maka ada di antara } \\
\text { mereka yang beriman dan ada } \\
\text { (pula) di antara mereka yang } \\
\text { kafir. Seandainya Allah } \\
\text { menghendaki, tidaklah mereka } \\
\text { berbunuh-bunuhan. Akan tetapi } \\
\text { Allah berbuat apa yang } \\
\text { dikehendaki-Nya. }\end{array}$ & $\begin{array}{l}\text { Allah } \\
\text { meninggikan } \\
\text { beberapa derajat } \\
\text { bagi sebagian } \\
\text { rasul. }\end{array}$ & $\begin{array}{l}\text { Sebagian rasul } \\
\text { ditinggikan } \\
\text { derajatnya. }\end{array}$ \\
\hline 2 & 3: 139 & $\begin{array}{l}\text { Janganlah kamu bersikap lemah, } \\
\text { dan janganlah (pula) kamu } \\
\text { bersedih hati, padahal kamulah } \\
\text { orang-orang yang paling tinggi } \\
\text { (derajatnya), jika kamu } \\
\text { orang-orang yang beriman. }\end{array}$ & $\begin{array}{l}\text { Saat mendapat } \\
\text { kesulitan, orang } \\
\text { yang beriman } \\
\text { memiliki derajat } \\
\text { tinggi. }\end{array}$ & $\begin{array}{l}\text { Orang beriman } \\
\text { yang berhasil } \\
\text { melalui kesulitan } \\
\text { memiliki derajat } \\
\text { yang tinggi. }\end{array}$ \\
\hline 3 & 4: $95-96$ & $\begin{array}{l}\text { Tidaklah sama antara mukmin } \\
\text { yang duduk (yang tidak turut } \\
\text { berperang) yang tidak } \\
\text { mempunyai udzur, dengan } \\
\text { orang-orang yang berjihad di } \\
\text { jalan Allah dengan harta mereka } \\
\text { dan jiwanya. Allah melebihkan } \\
\text { orang-orang yang berjihad } \\
\text { dengan harta dan jiwanya atas } \\
\text { orang-orang yang duduk satu } \\
\text { derajat. Kepada masing-masing } \\
\text { mereka Allah menjanjikan } \\
\text { pahala yang baik (surga) dan } \\
\text { Allah melebihkan orang-orang }\end{array}$ & $\begin{array}{l}\text { Orang mukmin } \\
\text { yang berjihad } \\
\text { dilebihkan satu } \\
\text { derajat dibanding } \\
\text { orang yang hanya } \\
\text { duduk tanpa } \\
\text { memiliki } \\
\text { halangan. Orang } \\
\text { yang berjihad } \\
\text { diberikan derajat } \\
\text { berupa pahala } \\
\begin{array}{l}\text { yang besar, } \\
\text { ampunan, dan } \\
\text { rahmat. }\end{array}\end{array}$ & $\begin{array}{lr}\text { Orang } & \text { mukmin } \\
\text { yang } & \text { mau } \\
\text { berjihad dengan } \\
\text { harta dan jiwa } \\
\text { memiliki satu } \\
\text { derajat } \\
\text { tinggi. lebih } \\
\text { Pahala yang } \\
\text { besar dalam } \\
\text { bentuk derajat } \\
\text { tinggi, ampunan } \\
\text { dan rahmat. }\end{array}$ \\
\hline
\end{tabular}




\begin{tabular}{|c|c|c|c|c|}
\hline & & $\begin{array}{l}\text { yang berjihad atas orang yang } \\
\text { duduk dengan pahala yang besar, } \\
\text { (yaitu) beberapa derajat } \\
\text { daripada-Nya, ampunan serta } \\
\text { rahmat. Dan adalah Allah Maha } \\
\text { Pengampun lagi Maha } \\
\text { Penyayang. }\end{array}$ & & \\
\hline 4 & $\begin{array}{l}\text { 6: } 83 \text {, } \\
86, \text { dan } \\
87\end{array}$ & $\begin{array}{l}\text { - Dan itulah hujjah Kami yang } \\
\text { Kami berikan kepada Ibrahim } \\
\text { untuk menghadapi kaumnya. } \\
\text { Kami tinggikan siapa yang Kami } \\
\text { kehendaki beberapa derajat. } \\
\text { Sesungguhnya Tuhanmu Maha } \\
\text { Bijaksana lagi Maha } \\
\text { Mengetahui. } \\
\text { - Dan Ismail, Alyasa, Yunus dan } \\
\text { Lut. Masing-masingnya Kami } \\
\text { lebihkan derajatnya di atas umat } \\
\text { (di masanya), } \\
\text { - (Dan Kami lebihkan pula } \\
\text { derajat) sebahagian dari } \\
\text { bapak-bapak mereka, keturunan } \\
\text { mereka dan saudara-saudara } \\
\text { mereka. Dan Kami telah memilih } \\
\text { mereka (untuk menjadi nabi-nabi } \\
\text { dan rasul-rasul) dan Kami } \\
\text { menunjuki mereka ke jalan yang } \\
\text { lurus. }\end{array}$ & 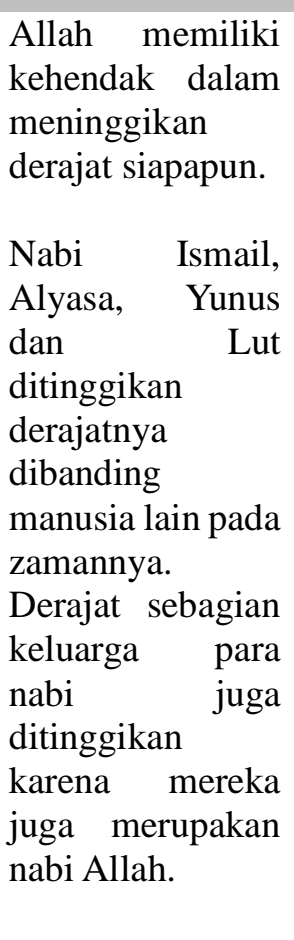 & $\begin{array}{l}\text { Allah berhak } \\
\text { meninggikan } \\
\text { derajat siapapun. } \\
=\text { Persis dengan } \\
\text { Tabel 2.a, No. } 1\end{array}$ \\
\hline 5 & $6: 132$ & $\begin{array}{l}\text { Dan masing-masing orang } \\
\text { memperoleh derajat-derajat } \\
\text { (seimbang) dengan apa yang } \\
\text { dikerjakannya. Dan Tuhanmu } \\
\text { tidak lengah dari apa yang } \\
\text { mereka kerjakan. }\end{array}$ & $\begin{array}{l}\text { Allah akan } \\
\text { memberikan } \\
\text { derajat kepada } \\
\text { manusia atas apa } \\
\text { yang dikerjakan, } \\
\text { karena Allah } \\
\text { selalu } \\
\text { mengetahui apa } \\
\text { yang manusia } \\
\text { kerjakan. }\end{array}$ & $\begin{array}{l}\text { Derajat yang } \\
\text { didapat sesuai } \\
\text { dengan pekerjaan } \\
\text { yang dilakukan. }\end{array}$ \\
\hline 6 & $6: 165$ & $\begin{array}{l}\text { Dan Dialah yang menjadikan } \\
\text { kamu penguasa-penguasa di } \\
\text { bumi dan Dia meninggikan } \\
\text { sebahagian kamu atas } \\
\text { sebahagian (yang lain) beberapa } \\
\text { derajat, untuk mengujimu } \\
\text { tentang apa yang diberikan-Nya } \\
\text { kepadamu. Sesungguhnya } \\
\text { Tuhanmu ama cepat } \\
\text { siksaan-Nya, dan sesungguhnya } \\
\text { Dia Maha Pengampun lagi Maha }\end{array}$ & $\begin{array}{l}\text { Penguasa bumi } \\
\text { atau pemimpin } \\
\text { ditinggikan } \\
\text { derajatnya oleh } \\
\text { Allah, karena } \\
\text { Allah akan } \\
\text { menguji } \\
\text { pemimpin atas } \\
\text { apa yang sudah } \\
\text { diberikan. }\end{array}$ & $\begin{array}{l}\text { Derajat } \\
\text { pemimpin yang } \\
\text { ditinggikan, } \\
\text { dijadikan alat } \\
\text { untuk menguji } \\
\text { rasa syukur } \\
\text { mereka. }\end{array}$ \\
\hline
\end{tabular}




\begin{tabular}{|c|c|c|c|c|}
\hline & & Penyayang. & & \\
\hline 7 & $7: 176$ & $\begin{array}{l}\text { Dan kalau Kami menghendaki, } \\
\text { sesungguhnya Kami tinggikan } \\
\text { (derajat) nya dengan ayat-ayat } \\
\text { itu, tetapi dia cenderung kepada } \\
\text { dunia dan menurutkan hawa } \\
\text { nafsunya yang rendah, maka } \\
\text { perumpamaannya seperti anjing } \\
\text { jika kamu menghalaunya } \\
\text { diulurkannya lidahnya dan jika } \\
\text { kamu membiarkannya dia } \\
\text { mengulurkan lidahnya (juga). } \\
\text { Demikian itulah perumpamaan } \\
\text { orang-orang yang mendustakan } \\
\text { ayat-ayat Kami. Maka } \\
\text { ceritakanlah (kepada mereka) } \\
\text { kisah-kisah itu agar mereka } \\
\text { berpikir. }\end{array}$ & $\begin{array}{l}\text { Allah bisa saja } \\
\text { meninggikan } \\
\text { derajat seseorang } \\
\text { melalui ayat-ayat } \\
\text { Nya }\end{array}$ & $\begin{array}{l}=\text { Persis dengan } \\
\text { Tabel 2.a, No. } 4\end{array}$ \\
\hline 8 & 8: 4 & $\begin{array}{l}\text { Itulah orang-orang yang beriman } \\
\text { dengan sebenar-benarnya. } \\
\text { Mereka akan memperoleh } \\
\text { beberapa derajat ketinggian di } \\
\text { sisi Tuhannya dan ampunan serta } \\
\text { rezeki (nikmat) yang mulia. }\end{array}$ & $\begin{array}{l}\text { Orang yang } \\
\text { beriman dengan } \\
\text { benar, maka akan } \\
\text { ditinggikan } \\
\text { derajatnya di sisi } \\
\text { Allah. }\end{array}$ & $\begin{array}{l}\text { Orang yang } \\
\text { serius beriman } \\
\text { memiliki derajat } \\
\text { yang lebih tinggi } \\
\text { di sisi Allah. }\end{array}$ \\
\hline 9 & $9: 20$ & $\begin{array}{l}\text { Orang-orang yang beriman dan } \\
\text { berhijrah serta berjihad di jalan } \\
\text { Allah dengan harta benda dan } \\
\text { diri mereka, adalah lebih tinggi } \\
\text { derajatnya di sisi Allah; dan } \\
\text { itulah orang-orang yang } \\
\text { mendapat kemenangan. }\end{array}$ & $\begin{array}{l}\text { Orang beriman, } \\
\text { berhijrah, dan } \\
\text { berjihad } \\
\text { menggunakan } \\
\text { harta dan diri } \\
\text { mereka maka } \\
\text { memiliki derajat } \\
\text { yang tinggi. }\end{array}$ & $\begin{array}{l}\text { Orang yang } \\
\text { mendapatkan } \\
\text { derajat tinggi } \\
\text { diantaranya } \\
\text { adalah: orang } \\
\text { beriman, } \\
\text { berhijrah, dan } \\
\text { berjihad harta } \\
\text { serta jiwa. }\end{array}$ \\
\hline 10 & $12: 76$ & $\begin{array}{l}\text { Maka mulailah Yusuf } \\
\text { (memeriksa) karung-karung } \\
\text { mereka sebelum (memeriksa) } \\
\text { karung saudaranya sendiri, } \\
\text { kemudian dia mengeluarkan } \\
\text { piala raja itu dari karung } \\
\text { saudaranya. Demikianlah Kami } \\
\text { atur untuk (mencapai maksud) } \\
\text { Yusuf. Tiadalah patut Yusuf } \\
\text { menghukum saudaranya } \\
\text { menurut undang-undang raja, } \\
\text { kecuali Allah menghendakinya. } \\
\text { Kami tinggikan derajat orang } \\
\text { yang Kami kehendaki: dan di } \\
\text { atas tiap-tiap orang yang } \\
\text { berpengetahuan itu ada lagi Yang } \\
\text { Maha Mengetahui. }\end{array}$ & $\begin{array}{l}\text { Allah } \\
\text { meninggikan } \\
\text { derajat siapa saja } \\
\text { yang memang } \\
\text { pantas untuk } \\
\text { mendapatkannya. }\end{array}$ & $\begin{array}{l}=\text { Persis dengan } \\
\text { Tabel 2.a, No. } 4 \\
\text { dan No. } 7\end{array}$ \\
\hline
\end{tabular}


Tabel 2.b. Memaknai Kata Derajat

\begin{tabular}{|c|c|c|c|c|}
\hline No & $\begin{array}{l}\text { QS.: } \\
\text { Ayat }\end{array}$ & Terjemah Al-Quran & Pesan Ayat & $\begin{array}{l}\text { Kesimpulan } \\
\text { Sementara }\end{array}$ \\
\hline 11 & 40: 15 & $\begin{array}{l}\text { (Dialah) Yang Maha Tinggi } \\
\text { derajat-Nya, } \\
\text { mempunyai Arasy, Yang } \\
\text { mengutus Jibril dengan } \\
\text { (membawa) perintah-Nya } \\
\text { kepada siapa yang } \\
\text { dikehendaki-Nya di antara } \\
\text { hamba-hamba-Nya, supaya } \\
\text { dia memperingatkan } \\
\text { (manusia) tentang hari } \\
\text { pertemuan (hari kiamat). }\end{array}$ & $\begin{array}{l}\text { Allah memiliki derajat } \\
\text { yang paling tinggi } \\
\text { dibanding } \\
\text { makhluk-makhluknya, } \\
\text { memiliki Arasy dan } \\
\text { kekuasaan tertinggi. }\end{array}$ & $\begin{array}{l}\text { Pemilik derajat } \\
\text { tertinggi adalah } \\
\text { Allah Swt. }\end{array}$ \\
\hline 12 & 43: 32 & $\begin{array}{l}\text { Apakah mereka yang } \\
\text { membagi-bagi rahmat } \\
\text { Tuhanmu? Kami telah } \\
\text { menentukan antara mereka } \\
\text { penghidupan mereka dalam } \\
\text { kehidupan dunia, dan Kami } \\
\text { telah meninggikan } \\
\text { sebahagian mereka atas } \\
\text { sebahagian yang lain } \\
\text { beberapa derajat, agar } \\
\text { sebahagian mereka dapat } \\
\text { mempergunakan sebahagian } \\
\text { yang lain. Dan rahmat } \\
\text { Tuhanmu lebih baik dari apa } \\
\text { yang mereka kumpulkan. }\end{array}$ & $\begin{array}{l}\text { Hanya sebagian orang } \\
\text { yang ditinggikan } \\
\text { derajatnya, agar } \\
\text { sebagian orang } \\
\text { tersebut dapat } \\
\text { memanfaatkan } \\
\text { sebagian yang lain. }\end{array}$ & $\begin{array}{l}\text { Tidak semua } \\
\text { orang dipilih } \\
\text { Allah untuk } \\
\text { ditinggikan } \\
\text { derajatnya. } \\
\text { Orang yang } \\
\text { memiliki derajat } \\
\text { tinggi bisa } \\
\text { bermanfaat bagi } \\
\text { yang lainnya. }\end{array}$ \\
\hline 13 & 46: 19 & $\begin{array}{l}\text { Dan bagi masing-masing } \\
\text { mereka derajat menurut apa } \\
\text { yang telah mereka kerjakan } \\
\text { dan agar Allah mencukupkan } \\
\text { bagi mereka (balasan) } \\
\text { pekerjaan-pekerjaan mereka } \\
\text { sedang mereka tiada } \\
\text { dirugikan. }\end{array}$ & $\begin{array}{l}\text { Derajat yang } \\
\text { didapatkan, dengan } \\
\text { disesuaikan dikerjakan, } \\
\text { apa yang dalah balasan } \\
\text { dan ini adalah } \\
\text { yang cukup bagi } \\
\text { mereka }\end{array}$ & $\begin{array}{l}=\text { Persis dengan } \\
\text { Tabel 2.a, No. } 5\end{array}$ \\
\hline 14 & 57: 10 & $\begin{array}{l}\text { Dan mengapa kamu tidak } \\
\text { menafkahkan (sebagian } \\
\text { hartamu) pada jalan Allah, } \\
\text { padahal Allah-lah yang } \\
\text { mempusakai (mempunyai) } \\
\text { langit dan bumi? Tidak sama } \\
\text { di antara kamu orang yang } \\
\text { menafkahkan (hartanya) dan } \\
\text { berperang sebelum }\end{array}$ & $\begin{array}{l}\text { Allah memberikan } \\
\text { derajat lebih tinggi } \\
\text { bagi orang yang } \\
\text { berjihad atas harta } \\
\text { dan jiwanya sebelum } \\
\text { penaklukan Mekah } \\
\text { dibanding dengan } \\
\text { orang yang berjihad } \\
\text { setelah penaklukan }\end{array}$ & $\begin{array}{l}\text { Orang yang } \\
\text { berjihad harta } \\
\text { dan jiwa } \\
\text { sebelum } \\
\text { penaklukan } \\
\text { Mekah (sebelum } \\
\text { berperang) } \\
\text { mendapatkan } \\
\text { derajat lebih }\end{array}$ \\
\hline
\end{tabular}




\begin{tabular}{|c|c|c|c|c|}
\hline & & 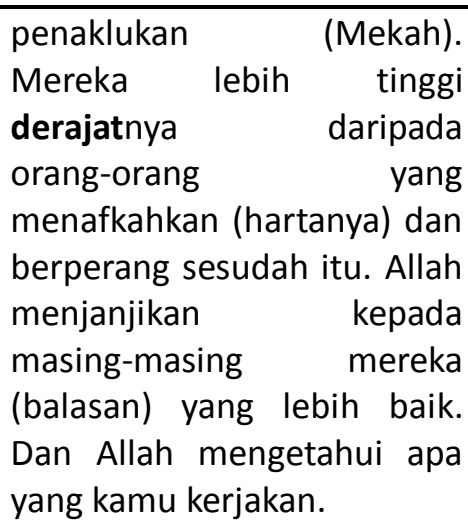 & Mekah. & tinggi. \\
\hline & 58: 11 & $\begin{array}{l}\text { Hai orang-orang yang } \\
\text { beriman, apabila dikatakan } \\
\text { kepadamu: } \\
\text { "Berlapang-lapanglah dalam } \\
\text { majelis", maka lapangkanlah, } \\
\text { niscaya Allah akan memberi } \\
\text { kelapangan untukmu. Dan } \\
\text { apabila dikatakan: } \\
\text { "Berdirilah kamu, maka } \\
\text { berdirilah, niscaya Allah akan } \\
\text { meninggikan orang-orang } \\
\text { yang beriman di antaramu } \\
\text { dan orang-orang yang diberi } \\
\text { ilmu pengetahuan beberapa } \\
\text { derajat. Dan Allah Maha } \\
\text { Mengetahui apa yang kamu } \\
\text { kerjakan. }\end{array}$ & $\begin{array}{l}\text { Orang yang beriman } \\
\text { dan berilmu } \\
\text { sama-sama Allah } \\
\text { tingkatkan derajatnya. }\end{array}$ & $\begin{array}{l}\text { Orang yang } \\
\text { berilmu } \\
\text { diberikan derajat } \\
\text { yang lebih tinggi } \\
\text { dibanding orang } \\
\text { yang beriman } \\
\text { saja. }\end{array}$ \\
\hline
\end{tabular}

Untuk memudahkan pemahaman atas penelusuran kata kunci "Derajat" maka lebih baik menjawab rumusan pembahasan poin kedua terlebih dahulu. Dalam membahas pertanyaan kedua yakni, "perilaku spesifik apa yang bisa meningkatkan derajat atau kedudukan seorang manusia?". Untuk lebih melengkapi pemahaman siapakah pihak-pihak yang berhak mendapat derajat tinggi tersebut, terdapat ayat yang menyatakan bahwa Allah pemilik derajat tertinggi (QS. Gafir [40]: 15), lalu setelah itu dikatakan dalam ayat lain, bahwa semua orang yang dikehendaki Allah pasti derajatnya ditinggikan (item No.4, No.7, dan No.10), serta adapun ayat yang menjelaskan bahwa hanya sebagian manusia saja yang mendapatkan derajat tinggi (item No.12). Maka bisa disimpulkan bahwa tidak semua manusia bisa mendapatkan derajat yang tinggi, tetapi hanya manusia-manusia tertentu yang dipilih Allah untuk mendapatkannya. Berikut manusia-manusia tertentu yang dimaksud Allah dalam mendapatkan derajat yang tinggi dibanding manusia lain:

1. Sebagian dari para Nabi dan Rasul;

2. para pemimpin;

3. orang berilmu; 
4. orang yang menjauhi hawa nafsu;

5. orang yang berjihad dengan harta dan jiwanya, sebelum perang dimulai;

6. orang berhijrah;

7. orang yang beramal shaleh, dan;

8. orang yang beriman.

Kategorisasi berurut dari poin 1 hingga 6 bukan hitungan pasti, tetapi peneliti analisis dari segi terjemah ayat, dengan kalimat pembeda berupa, "memperoleh derajat tertinggi", "ditinggikan beberapa derajat", "ditinggikan satu derajat", "ditinggikan derajatnya". Meski orang yang beriman ada di urutan akhir dalam versi peneliti, namun ini terjadi jika orang tersebut hanya BERIMAN saja. Tetapi jika orang beriman tersebut melakukan kegiatan lain dari poin 2 sampai 5 yang bisa kita katakan termasuk dalam perbuatan bajik, maka derajat yang dimiliki cenderung lebih tinggi, begitu pun sebaliknya. Penjelasan dari kategori ini yang merupakan penjelasan rumusan pembahasan kedua, secara langsung bisa menjawab rumusan pembahasan pertama, yakni "apakah dengan memiliki keimanan saja bisa menjadikan manusia memiliki derajat yang tinggi di hadapan Allah dan manusia lain?", ternyata sudah dijelaskan sebelumnya bahwa dengan beriman saja, itu tidak cukup, dibutuhkan usaha lain untuk menunjang dan melengkapi keimanan yang sudah dimiliki.

Sekali lagi peneliti tekankan, kategorisasi derajat manusia memang ada, tetapi yang penulis sertakan disini bukan suatu hitungan yang pasti. Peneliti menganalisis adanya peng-kategori-an derajat yang didapatkan manusia bisa ditentukan dari sebesar atau sebanyak apa pengorbanan yang sudah dilakukan, ini sesuai dengan item yang sudah ditemukan yakni dalam No. 5 dan No. 13. Disana dikatakan "Dan masing-masing orang memperoleh derajat-derajat (seimbang) dengan apa yang dikerjakannya" (QS. Al-An'am [6]:132, item No.5). Maka bisa diketahui melalui dua item ini, bahwa semakin besar atau banyak yang dikerjakan, yang dikorbankan seorang manusia disebabkan karena Allah Swt. maka akan semakin tinggi derajat yang dimiliki. Pertanyaan ketiga berkenaan dengan manfaat apa yang bisa didapatkan, jika seseorang sudah memiliki derajat yang tinggi. Pertanyaan ini terjawab oleh item No. 3, No. 6, dan No. 12. Untuk saat ini ditemukan tiga manfaat yang diperoleh dari derajat tinggi yakni:

1. Derajat tinggi merupakan kategori pahala besar;

2. derajat tinggi bisa dijadikan pengingat diri;

3. derajat tinggi menjadikan diri lebih bermanfaat untuk manusia lain.

Untuk item No.3 dikatakan bahwa pahala yang besar dari Allah berupa derajat yang tinggi, diberikan ampunan, serta rahmat dari Allah. Jadi dengan memperoleh derajat tinggi bisa memiliki arti mendapatkan balasan yang besar dibanding dengan balasan Allah lainnya. Selanjutnya dalam item No. 6 dikatakan, diberikannya derajat yang tinggi bisa dijadikan ujian bagi orang yang menerimanya. Dalam item 
ini ada peng-khusus-an untuk para pemimpin, derajat yang tinggi menjadikan mereka selalu ingat atas apa yang Allah berikan selama ini, sehingga mereka berusaha untuk menjaga dan menggunakan nikmat yang sudah diberikan dengan cara yang baik, sebagai bentuk terimakasih dari derajat yang sudah ditinggikan oleh Allah.

Item yang terakhir adalah No.12 yang menjelaskan bahwa, dengan derajat tinggi menjadikan orang tersebut bermanfaat bagi orang lain. Pernyataan ini sudah sangat jelas, karena orang yang memiliki derajat lebih tinggi pasti memiliki keunggulan bisa dari segi ilmu, atau keimanannya, atau kesabarannya, atau kekuasaan dan pengaruhnya atau bisa juga unggul dari segi materi yang dimiliki dibandingkan dengan yang lainnya, ini yang menjadikan alasan kenapa orang-orang tersebut bisa bermanfaat bagi yang lainnya.

\section{Keterhubungan antara Penderitaan dan Derajat}

Pasca penelusuran kata kunci Penderitaan dan Derajat, ternyata ditemukan adanya keterhubungan pembahasan. Penderitaan bisa bermakna kesulitan, kesedihan, keletihan, dan perasaan lainnya yang membuat kita tidak nyaman. Manusia pada umumnya jika menuruti hawa nafsu, ingin melakukan apapun sesuai kehendaknya sendiri saja, tidak memperhatikan orang lain, tetapi karena ada sejumlah aturan dan norma yang harus dipatuhi sebagai makhluk yang bermasyarakat, maka diperlukan filter untuk melakukan kesenangan tersebut.

Hasil penelusuran kata Penderitaan, ditemukan kesimpulan bahwa penderitaan ada untuk membuat pemahaman manusia mengenai kehidupan bertambah bijak, tidak melulu memandang negatif atas apa-apa yang bukan menjadi urusannya. Kemudian beralih kepada pembahasan mengenai kata Derajat, disana ditemukan bahwa konsep derajat tidak hanya sekadar orang yang berbuat baik sekali lalu memiliki derajat yang bagus, tetapi terdapat kategori yang secara tidak langsung terlihat berdasarkan tingkat amal yang dilakukan oleh setiap individu.

Contoh keterhubungannya bisa menganalisis pada QS. At-Taubah: 128 pada tabel 1. no.4, disana dijelaskan bahwa Rasulullah tidak mau umatnya merasakan kesusahan maupun menderita, namun beliau tentu tidak memiliki kuasa atas hal itu, sehingga usaha yang beliau lakukan adalah mendoakan umatnya. Kemudian beralih pada pembahasan mengenai kategori derajat berdasarkan amal manusia, diantaranya ada pemimpin, orang yang berjihad, orang berilmu, berhijrah. Lantas? Apakah setiap orang yang memiliki status tersebut, tidak mengalami kesusahan dalam menjalankan amalnya?, tentu ada sekian kesusahan dan pengorbanan yang mereka lakukan, meskipun terasa menderita tetapi mereka paham bahwa hal tersebut bukan hal yang harus diratapi atau dikeluhkan, sehingga dengan kesabaran mereka jalani amal tersebut. Ganjaran yang didapat pun setimpal dengan mendapat derajat yang tinggi di mata Allah, bahkan mendapat kedudukan yang spesial juga di tengah 
masyarakat karena amalnya yang bermanfaat.

Selanjutnya kita ambil contoh menggunakan hasil penelusuran kata kunci Derajat, pada QS. Ali Imran: 139 pada tabel 2.a no. 2 dengan terjemah berikut, "Janganlah kamu bersikap lemah, dan janganlah (pula) kamu bersedih hati, padahal kamulah orang-orang yang paling tinggi (derajatnya), jika kamu orang-orang yang beriman”. Ayat ini memiliki pesan untuk menyemangati umat Muslim yang sedang menjalani perang Uhud, tentu menjadi pasukan perang bisa merasakan berbagai macam emosi, marah, takut, kecewa, sakit dan menderita, terlebih saat perang ini terjadi, umat Muslim mengalami kekalahan sehingga emosi yang mereka rasakan pun bercampur aduk. Namun dalam ayat tersebut dikatakan agar tidak bersedih hati, karena Allah memberikan ganjaran atas tingginya derajat mereka jika mampu belajar dari kejadian yang ada.

Penjelasan diatas pun bisa didukung dengan penjelasan QS. An-Nisa: 95-96 pada tabel 2.a no.3, yang menyatakan perbedaan pasukan Muslim yang ikut berperang secara langsung dengan yang yang hanya duduk saja, menunggu keadaan mereda. Derajat mereka di hadapan Allah berbeda, karena sebagian yang lain mengorbankan semuanya, rela melakukan peperangan meskipun mengetahui bagaimana rasa sakitnya terluka berada di medan perang. Berangkat dari hasil analisis tersebut, berarti memang ditemukan adanya keterhubungan antara besarnya rasa penderitaan dibarengi dengan usaha yang ikhlas terhadap tingginya derajat manusia di mata Allah.

\section{SIMPULAN}

Konsep derajat manusia dalam perspektif Alquran berbeda dengan pemahaman yang terlanjur mengakar di tengah masyarakat. Sebagian besar masyarakat terlanjur berpikiran bahwa derajat manusia sesuai dengan keadaan ekonominya, walaupun ada beberapa dari mereka yang sudah mengetahui bahwa pemahaman yang mengakar di masyarakat ini salah, kemudian ada pemahaman lain yang mengatakan bahwa yang membedakan derajat manusia dengan yang lainnya adalah keimanan, ternyata pemahaman ini juga masih belum tepat atau lengkap.

Hasil kajian ini menemukan hasil bahwa tingginya derajat seseorang tidak sebatas dia cukup beriman saja, tetapi diperlukan amal yang lebih besar, serta dibarengi kerelaan saat dihadapkan pada situasi sulit yang membuatnya menderita. Ini berlaku pada masyarakat dulu maupun sekarang, dalam Alquran sendiri diceritakan dengan jelas masyarakat dulu juga sebenarnya memberikan tanda keluhan saat menderita walaupun mereka hidup bersama Rasulullah, begitu pun dengan masyarakat masa kini. Namun, saat manusia melakukan kesalahan dalam mengelola emosinya, derajat manusia tidak turun begitu saja, Allah masih memberikan kesempatan dengan ujian-Nya yang lain baik dengan diberi kenikmatan atau kesedihan kembali, dan saat manusia yang gagal sebelumnya mampu belajar 
dari kesalahan yang telah ia perbuat, maka Allah memberikan kembali ganjaran yang setimpal atas usahanya. Melalui kajian ini, bisa dipahami bahwa sifat baik Allah tidak selalu ditemukan pada hal yang menurut manusia sebuah kenikmatan maupun kesenangan, tetapi kita bisa temukan juga dalam sebuah penderitaan.

\section{DAFTAR PUSTAKA}

Chirzin, M. (2012). Kamus Pintar Al-Qur'an. Jakarta: Zaman.

Daradjat, Z. (2010). Ilmu Jiwa Agama. Jakarta: Bulan Bintang.

Darmawanti, I. (2012). Hubungan antara Tingkat Religiusitas dengan Kemampuan dalam Mengatasi Stres (Coping Stress). Jurnal Psikologi Teori Dan Terapan, 2(2), 102. https://doi.org/10.26740/jptt.v2n2.p102-107.

Fakhyadi, D. (2017). Perang Tabuk: Sebuah Distorsi Sejarah Kebudayaan Islam (Kajian Sosio-Historis atau Sirah al-Nabawiyyah). Ijtihad, 33(1), 45-52.

Hasan, M. S. (2017). Manajemen Marah dan Urgensinya dalam Pendidikan. Al-Idaroh, 1(02), 84-107.

Istiningtyas, L. (2014). Humor Dalam Kajian Psikologi Islam. Jurnal Ilmu Agama, 15(1), 37-59.

Kumala, O. D., Kusprayogi, Y., \& Nashori, F. (2017). Efektivitas Pelatihan Dzikir dalam Meningkatkan Ketenangan Jiwa pada Lansia Penderita Hipertensi. Psympathic: Jurnal Ilmiah Psikologi, 4(1), 55-66. https://doi.org/10.15575/psy.v4i1.1260.

Nadhiroh, Y. F. (2015). Pengendalian Emosi. Jurnal Saintifika Islamica, 2(1), 53-63.

Rahmat, M. (2017). Model/Metode Pembelajaran Digital Quran secara Tematik. Jakarta: Direktorat Jenderal Kekayaan Intelektual.

Shihab, M. Q. (2000). Wawasan Al Quran. Bandung: Mizan.

Shihab, M. Q. (2002). Tafsir Al-Mishbah. Jakarta: Lentera Hati.

Supiana. (2017). Metodologi Studi Islam. Bandung: Remaja Rosdakarya.

Wage. (2015). Mewujudkan Islam Berwawasan Rahmatan Lil Alamin. Islamadina, XIV, $119-137$.

Wiryoutomo, P. (2009). Hikmah Sabar. Jakarta: Qultum Media. 